\title{
Teknik Effleurage Massage terhadap Nyeri Dissmenore
}

\author{
Putri Andanawarih, Miftachul Jannah, Swasti Artanti \\ Email: poetry_andana@yahoo.com \\ D-III Kebidanan, Akademi Kebidanan Harapan Ibu Pekalongan, Indonesia \\ J1. Sriwijaya No 7 Kota Pekalongan \\ Telp. 085102998866
}

\begin{abstract}
Abstrak
Keluhan dissmenore terjadi pada $60-90 \%$ remaja dan penyebab paling sering alasan ketidakhadiran kuliah dan pengurangan aktivitas sehari-hari. Dissmenore yang dirasakan berupa nyeri atau rasa sakit siklik bersamaan dengan menstruasi serta sering dirasakan seperti rasa kram pada perut serta dapat menjalar ke punggung, disertai rasa mual dan muntah. Penanganan dissmenore dapat dilakukan dengan cara teknik effleurage, teknik effleurage menstrimulus rangsangan pada perut yang mengalami nyeri yang dapat memberikan efek nyaman. Jenis penelitian ini menggunakan eksperimen semu, Desain penelitian quasi experiment, Populasi dalam penelitian ini menggunakan teknik random sampling dengan jumlah pelitian ini sebanyak 15. Hasil uji normalitas data nyeri menstruasi sebelum diberikan perlakuan sebesar 0,33 dan setelah diberikan perlakuanan sebesar 0,14 yang berarti $\mathrm{p}>0,05$. Hal ini menunjukkan bahwa data berdistribusi normal, maka uji statistik yang digunakan adalah uji Paired T-test. Berdasarkan uji signifikansi Paired T-test didapatkan bahwa nilai signifikansi (p) yaitu 0,00 menggunakan ketentuan bahwa derajat kesalahan $(\alpha)$ adalah 5\% atau 0,05 sehingga ada perbedaan antara nyeri haid sebelum dilakukan pijatan efflurage dan sesudah dilakukan pijatan efflurage. Pada penelitian ini didapatkan hasil terjadi penurunan tingkat nyeri haid sesudah dilakukan pijatan efflurage dibandingkan dengan sebelum dilakukan pijatan efflurage, hal ini membuktikan bahwa pijatan dengan teknik efflurage dapat menurunkan nyeri.
\end{abstract}

Kata Kunci: teknik effleurage massage; nyeri desminorre.

\begin{abstract}
Complaints of dissmenorrhea occur in $60-90 \%$ of adolescents and are the most frequent causes of absenteeism from lectures and reduced daily activities. Dissmenorrhea that is felt in the form of pain or cyclic pain along with menstruation and often feels like cramps in the stomach and can spread to the back, accompanied by nausea and vomiting. Handling of dissmenorrhea can be done by means of the effleurage technique, the effleurage technique to stimulate the stimulation of the stomach that is experiencing pain which can provide a comfortable effect. This type of research used a quasi-experimental, quasi-experimental research design, the population in this study used a random sampling technique with a total of 15 . The results of the normality test of menstrual pain data before treatment were 0.33 and after treatment was 0.14 which means $p>0.05$. This shows that the data is normally distributed, so the statistical test used is the Paired T-test. Based on the Paired T-test significance test, it was found that the significance value (p) is 0.00 using the provision that the degree of error $(\alpha)$ is $5 \%$ or 0.05 so that there is a difference between menstrual pain before efflurage massage and after efflurage massage. In this study, it was found that there was a decrease in the level of menstrual pain after efflurage massage compared to before efflurage massage, this proves that massage with the efflurage technique can reduce pain.
\end{abstract}

Keywords: effleurage massage technique; desminorre pain. 
Jurnal Kebidanan Harapan Ibu Pekalongan

\section{Pendahuluan}

Dismenore merupakan salah satu masalah yang timbul selama atau sebelum menstruasi yang terjadi akibat peningkatan hormon prostaglandin yang dapat meningkatkan kontraksi uterus $^{(1)}$. Keluhan dissmenore terjadi pada 60\%-90\% remaja dan merupakan penyebab paling sering alasan ketidakhadiran kuliah dan pengurangan aktivitas sehari-hari ${ }^{(2)}$. Angka kejadian dissmenore di Indonesia sebesar $64,25 \%$ yang terdiri dari $54,89 \%$ dissmenore primer dan $9,36 \%$ dissmenore sekunder ${ }^{(3)}$.

Dissmenore yang dirasakan berupa nyeri atau rasa sakit siklik bersamaan dengan menstruasi serta sering dirasakan seperti rasa kram pada perut serta dapat menjalar ke punggung, disertai rasa mual dan muntah $^{(4)}$. Penanganan dissmenore dapat dilakukan dengan cara farmakologi, non-farmakologi dan dengan cara operasi. Salah satu cara mengatasi dissmenore adalah teknik effleurage dengan menstrimulus serabut taktil di kulit pada abdomen yang memberikan efek relaksasi pada otot abdomen sehingga spasme otot abdomen berkurang dan dapat memberikan efek distraksi sehingga sinyal nyeri dapat dihambat ${ }^{(5)}$.

\section{Metode Penelitian}

Jenis penelitian ini menggunakan eksperimen semu (quasi experimental designs). Menurut Notoatmodjo (2010), metode eksperimen adalah suatu penelitian dengan melakukan kegiatan percobaan (experiment) yang bertujuan untuk mengetahui gejala atau pengaruh yang timbul akibat dari adanya perlakuan tertentu atau eksperimen tersebut.

Desain penelitian yang digunakan dalam penelitian ini adalah quasi experiment yaitu desain ini tidak mempunyai pembatas yang ketat terhadap randomisasi, dan pada saat yang sama dapat mengontrol ancamanancaman validitas. Selain itu, disebut eksperimen semu karena eksperimen ini belum atau tidak memiliki ciri-ciri rancangan eksperimen sebenarnya, karena variabel-variabel yang seharusnya dikontrol atau dimanipulasi tidak dapat atau sulit dilakukan.

Populasi dalam penelitian ini adalah mahasiswi Akademi Kebidanan Harapan Ibu Pekalongan.

Pengambilan sampel penelitian menggunakan teknik random sampling. Jumlah sampel yang diambil untuk penelitian ini sebanyak 15 orang yang terbagi menjadi 1 kelompok perlakuan pretest-posttest. Penentuan jumlah sampel penelitian eksperimen ditetapkan sebanyak 10-20 sampel untuk menghindari bias penelitian sesuai dengan teori Roscue (1975) dalam Sekaran ${ }^{(7)}$.

\section{Hasil dan Pembahasan}

Karakteristik respondan dalam penelitian ini yaitu berusia 19 tahun sebanyak 7 orang (46,7\%), 20 tahun sebanyak 3 orang $(20,0 \%)$, usia 21 tahun dan 22 tahun masing-masing sebanyak 2 orang (13.3\%) dan usia terendah adalah 18 tahun yaitu 1 orang $(6,7 \%)$.

Hasil uji normalitas data nyeri menstruasi sebelum diberikan perlakuan sebesar 0,33 dan setelah diberikan perlakuanan sebesar 0,14 yang berarti $\mathrm{p}>0,05$. Hal ini menunjukkan bahwa data berdistribusi normal, maka uji statistik yang digunakan adalah uji Paired T-test. Berdasarkan uji signifikansi Paired T-test melalui 
Jurnal Kebidanan Harapan Ibu Pekalongan

program SPSS for windows versi 16,0 didapatkan bahwa nilai signifikansi (p) yaitu 0,00 menggunakan ketentuan bahwa derajat kesalahan $(\alpha)$ adalah $5 \%$ atau 0,05 sehingga ada perbedaan antara nyeri haid sebelum dilakukan pijatan efflurage dan sesudah dilakukan pijatan efflurage. Pada penelitian ini didapatkan hasil bahwa terjadi penurunan tingkat nyeri haid sesudah dilakukan pijatan efflurage dibandingkan dengan sebelum dilakukan pijatan efflurage, hal ini membuktikan bahwa pijatan dengan teknik efflurage dapat menurunkan nyeri saat haid karena pemberian pijatan effleurage pada abdomen yang menstimulasi serabut taktil dikulit sehingga sinyal nyeri dapat dihambat. Stimulasi pada kulit dengan effleurage dapat menghasilkan pesan yang dikirim melalui serabut A- $\delta$, yang mengakibatkan gerbang tertutup sehingga korteks serebri tidak menerima sinyal nyeri dan intensitas nyeri berubah karena serabut ini dapat menghantarkan nyeri secara cepat, hal ini sesuai dengan yang dikemukakan oleh Potter \& Perry ${ }^{(8)}$.

Hasil penelitian ini didukung penelitian sebelumnya yang dilakukan oleh Tina Shinta Parulian, Junatri Sitompul, dan Anne Nur Oktrifiana pada ibu post partum dengan judul pengaruh teknik effleurage massage terhadap perubahan nyeri pada ibu post partum di rumah sakit sariningsih bandung, menunjukkan ada pengaruh teknik effleurage massage terhadap perubahan nyeri pada ibu post partum di Rumah Sakit Sariningsih Bandung ${ }^{(9)}$.

Hasil penelitian lainnya yang telah dilakukan oleh Fitrianingrum, Indanah, dan Suwarto pada Pasien
Post Appendictomy di Rumah Sakit Umum Daerah Kabupaten Kudus tahun 2013 menunjukkan bahwa terdapat pengaruh teknik relaksasi effleurage terhadap nyeri pada pasien post appendectomy ${ }^{(10)}$.

Hasil penelitian lainnya yaitu telah dilakukan oleh Trie Wahyu Agustina , Suri Salmiyati dengan judul Pengaruh Pemberian Effleurage Massage Aromatherapy Jasmine Terhadap Tingkat Dismenore Pada Mahasiswi Keperawatan Semester Iv Di Universitas 'Aisyiyah Yogyakarta menunjukkan bahwa teknik effleurage dapat menurunkan nyeri disminore $^{(11)}$. Berdasarkan penjelasan diatas bahwa penelitian yang telah dilakukan peneliti menunjukkan bahwa teknik effleurage massage dapat digunakan sebagai terapi nonfarmakologis untuk mengurangi nyeri saat haid yang sehingga merasa nyaman kembali saat haid.

\section{Kesimpulan}

Karakteristik usia responden menunjukkan mayoritas tertinggi berusia yaitu usia 19 tahun sebanyak 7 orang (46,7\%), 20 tahun sebanyak 3 orang $(20,0 \%)$, usia 21 tahun dan 22 tahun masing-masing sebanyak 2 orang $(13.3 \%)$ dan usia terendah adalah 18 tahun yaitu 1 orang $(6,7 \%)$. Skala rata-rata nyeri haid sebelum dilakukan pijatan efflurage yaitu 7.2, dengan nilai nyeri terendah pada skala 5 dan nilai nyeri tertinggi pada skala 9. Skala ratarata nyeri haid setelah dilakukan pijatan efflurage yaitu 5.4, dengan nilai nyeri terendah pada skala 3 dan nilai nyeri tertinggi pada skala 8 . Teknik pijatan efflurage mamapu menurunkan tingkat nyeri haid.

Sebaiknya peneliti dapat mengembangkan hasil penelitian menjadi bahan ajar untuk mengatasi 
Jurnal Kebidanan Harapan Ibu Pekalongan

nyeri haid kepada masyarakat luas. Mahasiswi yang telah mendapatkan pengetahuan tentang teknik pijatan efflurage mampu mengatasi nyeri haid yang dialami secara mandiri

\section{Daftar Pustaka}

[1] Manuaba, I.B.G., I.A. Chandranita Manuaba, dan I.B.G. Fajar Manuaba. Pengantar Kuliah Obstetri. Jakarta: Buku Kedokteran EGC, 2007.

[2] Lestari, Hesti, Jane Metusala, and Diana Yuliani Suryanto. Gambaran dismenorea pada remaja putri sekolah menengah pertama di Manado. Sari Pediatri 12.2, 2016: 99-102.

[3] Proverawati. Menarche Menstruasi Pertama penuh Makna. Yogyakarta: Nuha Medika, 2012.

[4] Fahmi, M.F. Pengaruh vitamin $E$ dalam mengurangi nyeri haid (dismenore) pada wanita usia muda yang dinilai dengan visual analog scale. Medan: Universitas Sumatera Utara, 2014.

[5] Astria, Indah, Sri Utami, and Wasisto Utomo. Efektifitas Kombinasi Teknik Slow Deep Breathing dan Teknik Effleurage terhadap Intensitas Nyeri Dismenorea. Jurnal Online Mahasiswa Program Studi Ilmu Keperawatan Universitas Riau. 2.2, 2015: 1169-1177.

[6] Notoatmojo, S. Metodologi Penelitian Kesehatan. Jakarta: Rineka Cipta, 2010.

[7] Sekaran, Uma. Metodologi Penelitian untuk Bisnis. Edisi 4. Jakarta: Salemba Empat, 2006.
[8] Potter, P.A, Perry, A.G. Buku Ajar Fundamental Keperawatan: Konsep, Proses dan Praktik. Edisi 4. Volume 2. Alih Bahasa: Renata Komalasari, dkk. Jakarta: EGC, 2006.

[9] Parulian, Tina Shinta, Junatri Sitompul, and A. N. Oktifriana. Pengaruh Teknik Effleurage Massage Terhadap Perubahan Nyeri Pada Ibu Post Partum Di Rumah Sakit Sariningsih Bandung, 2014.

[10] Fitrianingrum, Fitrianingrum, and Tri Suwarto. Pengaruh Tehnik Relaksasi Efflurage Terhadap Penurunan Nyeri Pada Pasien Post Appendictomy di Rumah Sakit Umum Daerah Kabupaten Kudus. Jurnal Ilmu Keperawatan dan Kebidanan 4.2, 2013.

[11] Agustina, Trie Wahyu, and Suri Salmiyati. Pengaruh Pemberian Effleurage Massage Aromatherapy Jasmine Terhadap Tingkat Dismenore Pada Mahasiswi Keperawatan Semester IV Di Universitas 'Aisyiyah Yogyakarta. Diss. 'Universitas' Aisyiyah Yogyakarta, 2017. 